\title{
Different Obstacles for Different Productivity Levels? An Analysis of Caribbean Firms
}

\section{Alison Cathles and Siobhan Pangerl}

Much of the literature relating firm characteristics to productivity and growth in Latin America and the Caribbean (LAC) either lumps Caribbean countries into one observation or tends to overlook them altogether. This is not because researchers want to exclude the Caribbean, but because the data deficit that often poses a challenge for the LAC region is even more extreme when it comes to Caribbean countries. Only a small fraction of over 100 identified indicators affecting growth are available for these countries. Further, limited availability of household data or fewer observations on firms is often prohibitive for standard methodological analysis of economic growth (Ruprah et al. 2014).

So, is an independent analysis of Caribbean firms even needed? The simple answer is yes. Small population size, geographical characteristics,
A. Cathles
UNU-MERIT
e-mail: cathles@merit.unu.edu
S. Pangerl
Inter-American Development Bank
e-mail: siobhanp@IADB.ORG
(C) Inter-American Development Bank 2016
M. Grazzi and C. Pietrobelli (eds.), Firm Innovation
and Productivity in Latin America and the Caribbean, DOI 10.1057/978-1-349-58151-1_7

207 
and main economic activities set Caribbean economies apart from most Latin American economies. As with Latin America, there is stark heterogeneity among and within Caribbean countries. Even though size may be a defining factor, it is lower productivity levels that define the declining growth of Caribbean economies relative to other small-sized economies (Ruprah et al. 2014). Increasingly, understanding macroeconomic trends requires an understanding of firm dynamics at a micro-level and productivity levels within and across industries (Syverson 2011). Therefore, Caribbean policymakers need this type of micro-data, analysis, and dissemination of information tailored to the region at their disposal. Recent firm-level data from the World Bank Enterprise Surveys (WBES) and the Productivity, Technology, and Innovation in the Caribbean (PROTEQin) Survey offer new opportunities to understand better the characteristics of Caribbean firms at different levels of productivity and the challenges or obstacles that they face in their daily operations.

The primary objective of this chapter is to fill a void in the literature about firms in the Caribbean through a comprehensive analysis of different firm characteristics and productivity. These firm-level characteristics are discussed at length in this book, but they are not directly applied to the Caribbean context. ${ }^{1}$

In the next section, we briefly contextualize the Caribbean economies within which firms are operating. Then we examine some of the basic firm characteristics that are frequently empirically linked with productivity, such as firm size, sector, age, exporter status, and use of information and communication technologies (ICT). We then deepen the analysis by specifically focusing on human capital, looking at both management and employees. The following section shows our analysis of firm-level labor productivity in relation to the main characteristics of firms (firm size, sector, age, exporter status, and ICT usage). Then we investigate the obstacles reported by the firms surveyed, specifically looking at the correlation and variation between obstacles and firm performance. Most of the analysis draws on the most recent wave of the WBES, which was carried out for the first time in 14 Caribbean countries in $2010 .^{2}$ We complement the analysis with data from the PROTEQin, which was conducted for the first time in 2013 in five Caribbean countries (Barbados, Belize, Jamaica, Guyana, and Suriname).

Overall, the results from the Caribbean micro-data tell a familiar story about firms with lower productivity levels - they tend to be smaller, to export less, and to have less human capital and technological inputs-but they also tend to report different obstacles to their current operations. If private-sector-led growth is expected to bolster the economy, then documentation and dissemination of the characteristics of this sector and the 
bottlenecks that lower and higher productivity firms are facing seems to be a necessary first condition for apt policymaking.

\section{Landscape of the Caribbean Economies}

This chapter uses data from 14 Caribbean economies. Table 7.1 shows that all of the Caribbean economies discussed in this chapter meet the definition of a small economy ${ }^{3}$ (except the Dominican Republic) based on having a population of less than three million people. The majority of the economies have a population of less than one million people. The econ-

Table 7.1 Brief characterization of Caribbean economies

\begin{tabular}{|c|c|c|c|c|c|c|}
\hline Country name & $\begin{array}{l}\text { GDP per } \\
\text { capita, PPP } \\
\text { (2012) }\end{array}$ & $\begin{array}{l}\text { Total } \\
\text { population } \\
\text { (2012) }\end{array}$ & $\begin{array}{l}\text { Largest industry } \\
\text { (value of annual } \\
\text { output) }\end{array}$ & $\begin{array}{l}\text { No. of } \\
\text { cargo } \\
\text { ports }\end{array}$ & Island & $\begin{array}{l}\text { No. of } \\
\text { firms } \\
(W B E S)\end{array}$ \\
\hline Antigua \& Barbuda & 20,385 & 89,069 & Tourism-based & 1 & Yes & 151 \\
\hline Bahamas & 22,705 & 371,960 & Tourism-based & 2 & Yes & 148 \\
\hline Barbados & 15,299 & 283,221 & Tourism-based & 1 & Yes & 150 \\
\hline Belize & 8313 & 324,060 & $\begin{array}{l}\text { Garment } \\
\text { production }\end{array}$ & 1 & No & 149 \\
\hline Dominica & 9829 & 71,684 & Soap & 2 & Yes & 150 \\
\hline $\begin{array}{l}\text { Dominican } \\
\text { Republic }\end{array}$ & 11,016 & $10,276,621$ & Tourism-based & 7 & $\begin{array}{l}\text { Part } \\
\text { of one }\end{array}$ & 360 \\
\hline Grenada & 10,975 & 105,483 & $\begin{array}{l}\text { Food and } \\
\text { beverages }\end{array}$ & 1 & Yes & 153 \\
\hline Guyana & 6054 & 795,369 & Bauxite & 2 & No & 162 \\
\hline Jamaica & 8521 & $2,707,805$ & Tourism-based & 6 & Yes & 375 \\
\hline St. Kitts \& Nevis & 20,100 & 53,584 & Tourism-based & 1 & Yes & 150 \\
\hline Saint Lucia & 10,359 & 180,870 & Tourism-based & 2 & Yes & 150 \\
\hline $\begin{array}{l}\text { St. Vincent \& } \\
\text { the Grenadines }\end{array}$ & 10,039 & 109,373 & Tourism-based & 2 & Yes & 154 \\
\hline Suriname & 15,174 & 534,541 & $\begin{array}{l}\text { Bauxite and } \\
\text { gold mining }\end{array}$ & 5 & No & 152 \\
\hline $\begin{array}{l}\text { Trinidad and } \\
\text { Tobago }\end{array}$ & 29,086 & $1,337,439$ & Petroleum & 6 & Yes & 366 \\
\hline Average & 14,132 & $1,231,506$ & & 3 & & \\
\hline Median & 10,995 & 303,641 & & 2 & & \\
\hline
\end{tabular}

Sources: Adapted from Ruprah et al. 2014. Data for no. of firms is from the WBES; data for GDP and population are from WDI; data for no. of ports is from CargoRouter.com; largest industry data is from the CIA Factbook; and island category is from Ruprah et al. 2014, except the Dominican Republic

Notes: The number of firms used in the two sections of this chapter on characteristics follow a preliminary cleaning of the data. GDP per capita are in constant 2011 PPP 
omy with the smallest population is St. Kitts \& Nevis, with a population of less than 54,000 (2012). In 2012, Trinidad and Tobago was reported to have the highest GDP per capita $(\$ 29,086$ in purchasing power parity $[\mathrm{PPP}]$ ) and Guyana had the lowest (\$6053 PPP). The median GDP per capita was almost $\$ 11,000$ in 2012 , with a mean of $\$ 14,132$ (in PPP terms).

The majority of the countries are islands where tourism is the largest industry. The number of ports is included in Table 7.1 to demonstrate the interconnectedness of the region to world trade networks, with the vast majority ${ }^{4}$ of the trade being transported by sea (Kaluza et al. 2010). Naturally, these economies face a small domestic market and can be at a disadvantage in global markets, although size does not have to be a binding constraint. Low productivity levels in the private sector in the region compared with similar small economies is a pressing concern for the future of the Caribbean (Ruprah et al. 2014).

Box 7.1. Recent developments in data collection in the Caribbean The release of the 2010 WBES was a starting point for comparable firmlevel data in the Caribbean. However, from the outset, researchers recognized the need for subsequent surveys in order to analyze the evolution of firms in the region. Fortunately, not too long after the first WBES was conducted, the region implemented the first wave of pseudo-follow-up surveys-the PROTEQin. This survey was commissioned by the Inter-American Development Bank (IDB), with funding from the Compete Caribbean Program, a regional private sector development and technical assistance initiative financed by the IDB; the United Kingdom Department for International Development; and Canada's Department of Foreign Affairs, and Trade and Development. The survey was executed in partnership with the Caribbean Development Bank. ${ }^{5}$ Administered between 2013 and 2014, the PROTEQin is a critical development in terms of data collection in the Caribbean and targeted establishments that were covered by the 2010 WBES in five economies: Barbados, Belize, Jamaica, Guyana, and Suriname. This decision allowed researchers a first opportunity to use panel data in analyzing firm-related issues in the Caribbean. ${ }^{6}$ 
The PROTEQin expands the scope of the WBES while also incorporating more detailed questions related to labor, productivity, technology and innovation for 727 firms. The dataset provides updated information on how firm characteristics and performance have evolved since the 2010 WBES. For this reason, we intersperse findings from the PROTEQin where possible to provide more recent information for selected countries and to check the robustness of the WBES data.

\section{Principal Characteristics of the Firms IN THE CARIBBEAN}

The dominating characteristics of the firms surveyed in the Caribbean are that they tend to be micro or small, concentrated in the services sectors, mature, and non-exporters. The documentation of the proportions of WBES firms with these attributes in each of the countries illustrates the heterogeneity between Caribbean countries and serves as a starting point for the rest of the chapter, establishing the particular features of the firms that are often linked to productivity in the literature.

The majority of firms are small (11 to 50 employees) or micro (10 employees or less). Figure 7.1 shows that $54 \%$ of the firms in St. Vincent \& the Grenadines are micro and $38 \%$ are small for a total of $92 \%$; a little over $6 \%$ of the firms are medium and just a shade over $1 \%$ are large. Very few large firms exist in any of the Caribbean countries. The Dominican Republic is the only country where more than $10 \%$ of the firms in the WBES are large enterprises. As we expect, typically countries with very small populations have a relatively greater percentage of micro and small firms. These countries appear on the left side of the graph, but there are some exceptions. For example, Barbados has a smaller population than Belize but a greater proportion of medium firms.

In a recently published note that maps the enterprises in LAC based on WBES data, there tend to be even more small and medium enterprises (SMEs) in the Caribbean than in the rest of LAC (94\% versus 90\%) and more firms are in the services sector (Francis et al. 2014). ${ }^{7}$ Although favorable views of SMEs contend that they spur competition and are a good source of employment, this argument only holds if the SMEs are productive, which implies that they are competitive and innovative (Pagés 2010). 


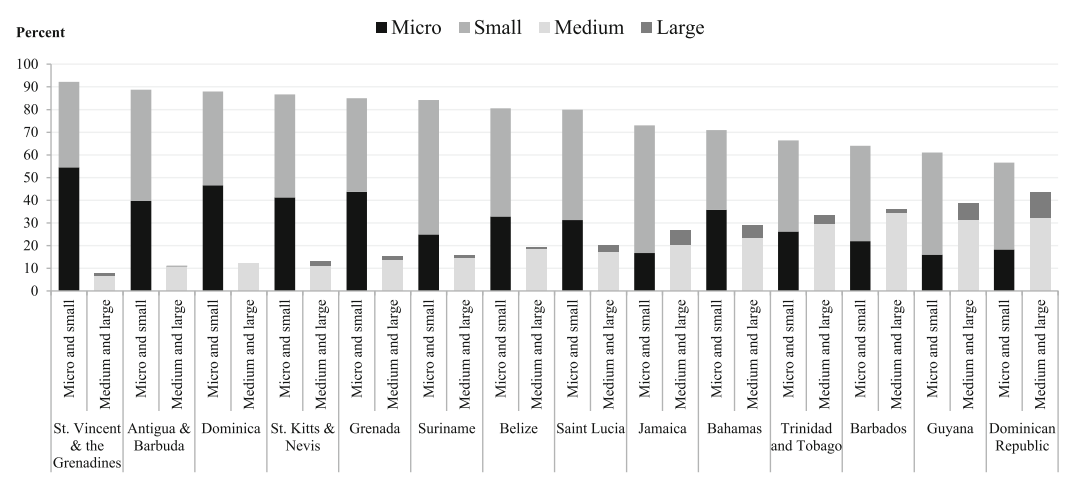

Fig. 7.1 Caribbean firms by size (number of employees)

Source: Authors' elaboration based on WBES data

Notes: firm size is based on the number of full-time, permanent employees in the previous fiscal year. The number of employees per size category is micro $(\leq 10)$, small $(>10$ and $\leq 50)$, medium $(>50$ and $\leq 250)$, and large (>250)

In fact, research using the global WBES found that, while small firms may have the largest shares of job creation and sales growth, large firms tend to display higher productivity growth (Ayyagari et al. 2011). Chapter 3 showed that large firms are more likely to invest in innovation and that those that do are more productive.

In most countries in the Caribbean, there is a greater proportion of firms in the services sector; however in Suriname, for example, firms are split roughly evenly between the services and manufacturing sectors. In the WBES, the firms self-classify as either being in manufacturing or in services. The corresponding workforce within the countries may be even more heavily concentrated in the services sector. In the LAC region, over $60 \%$ of the workforce is in services; in the Organization of East Caribbean States, the number is over $80 \%$ (Caribbean Knowledge Series 2013).

As discussed in Chap. 1 , and in line with recent research on productivity growth, it is the services sector that drags down overall productivity levels in LAC (Pagés 2010). Several studies have looked at the differences in productivity and innovation in the two sectors (Arias Ortiz et al. 2014; Crespi et al. 2014, for Latin America only; Arias Ortiz et al. 2012; IDB 2011a). These studies found that the allocative efficiency in the services sector tends to be much lower than in manufacturing. Knowing the sectoral composition of the firms in each country is a key element for analyzing the productivity of firms. 
In addition to being small and largely in the services sector, Caribbean firms also tend to be older. Very few new firms (defined as less than three years old) exist, whereas mature firms (defined as those in existence for over ten years) are much more prevalent. Mature firms represent the majority, except in Dominica, where the proportion of such firms dips below $50 \%$. In general, the LAC region tends to have a smaller proportion of young firms compared with other developing regions (Francis et al. 2014). The implications of age and productivity could go in either direction. Young firms are often seen as being a potential source of newness and innovation; however, mature firms may be seen as having stood the test of time.

The next important question relates to how connected these firms are. Given that firms tend to be smaller and older, have they adopted ICTs to connect to domestic or international markets? Are they internationally engaged? Figure 7.2 shows that cellphones and email are widely used in everyday business practices. More sophisticated ICTs, such as owning a website, which often requires some basic programming knowledge, are much less pervasive. There is a lot of heterogeneity within the Caribbean with regard to ICT, as there is throughout LAC, where evidence suggests that

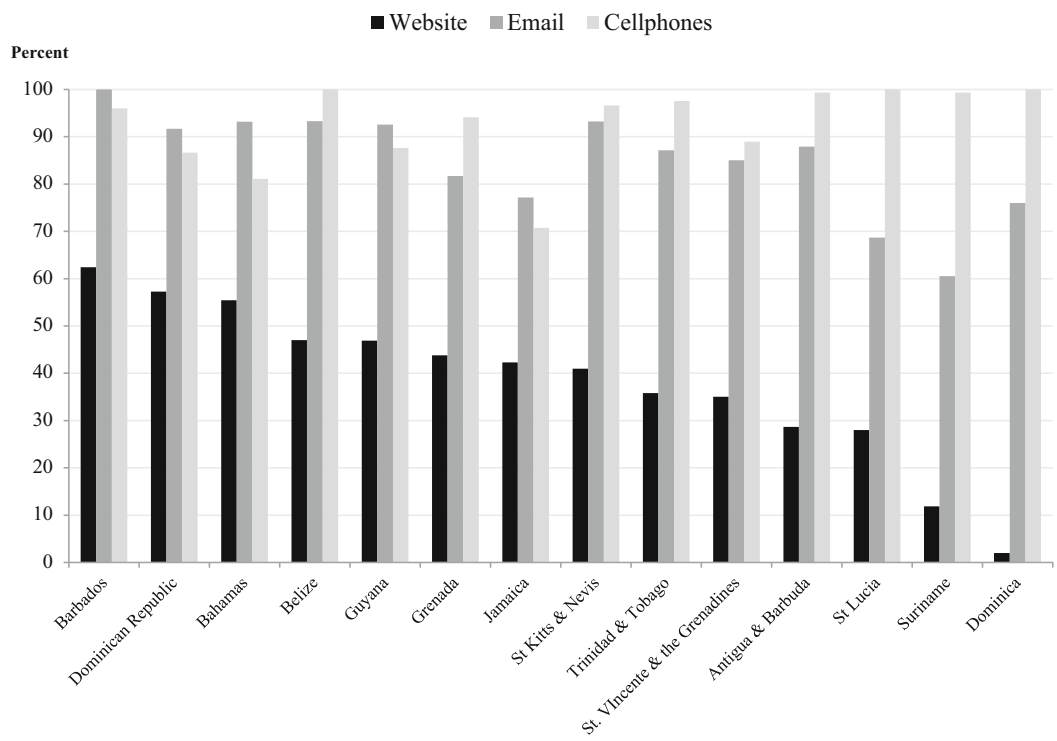

Fig. 7.2 ICT usage in the Caribbean Source: Authors' elaboration based on WBES data 
within-country differences are as notable as between-country differences (IDB 201lb). The low levels of website ownership by tourism-based economies suggest that there is room for gains by attracting new clients who are not being reached by conventional hotel and restaurant search methods.

The PROTEQin provides updated information about ICT penetration in select Caribbean countries. Firms were asked the same series of questions about email, websites, and cellphones for business operations. The improvements in these indicators vary by country. Countries like Barbados and Belize, which already showed relatively high levels in 2010, saw slight improvements in websites (Barbados and Belize) and cellphones (Barbados). With a 4\% improvement over 2010 in cellphone usage, Barbados reached $100 \%$ penetration in both cellphone and email usage to communicate with clients. Suriname and Jamaica showed significant improvements in ICT usage between the two survey periods. For example, in Jamaica, cellphone use increased by $24 \%$. Suriname saw sizeable increases in both website usage $(28 \%)$ and email usage (18\%). Guyana is the only country that showed declines in ICT penetration in both website and email usage. On the whole, for cellphone penetration, the PROTEQin shows improvement over the WBES 2010 average, with all five countries above $90 \%{ }^{8}$ To meet regional averages, Jamaica, Guyana, and Suriname need to improve email usage. Use of firm websites was by far the weakest area for the selected countries, with Barbados being the only one to outperform the 2010 regional average. Despite these gaps, the large improvements between 2010 and 2013 in some of the underperforming countries, like Jamaica and Suriname, should not be overlooked.

In terms of international linkages, the WBES data shows that most Caribbean firms are non-exporters (Fig. 7.3a); therefore, a very small proportion of sales are derived from either indirect or direct exports (Fig. 7.3b). In general, exporting is thought to be positively linked with productivity. A recent survey of micro-econometric studies from 33 developed and developing countries summarizes corroborative evidence from 1995 to 2004 (Wagner 2005). The author claimed that most of the differences were due to pre-entry self-selection into export markets rather than gains in productivity post-entry into the market (Wagner 2005). ${ }^{9}$ In addition to whether or not a firm is exporting, the average proportion of sales earned from exports ranges from $3 \%$ in Grenada to $16 \%$ in Dominica. Across the Caribbean, a very small average proportion of sales are being generated from indirect export sales.

Given the dominating characteristics of the firms covered in this section (small, old, and in the services sector), if policymakers want to help firms become more internationally engaged and connected through technology, 


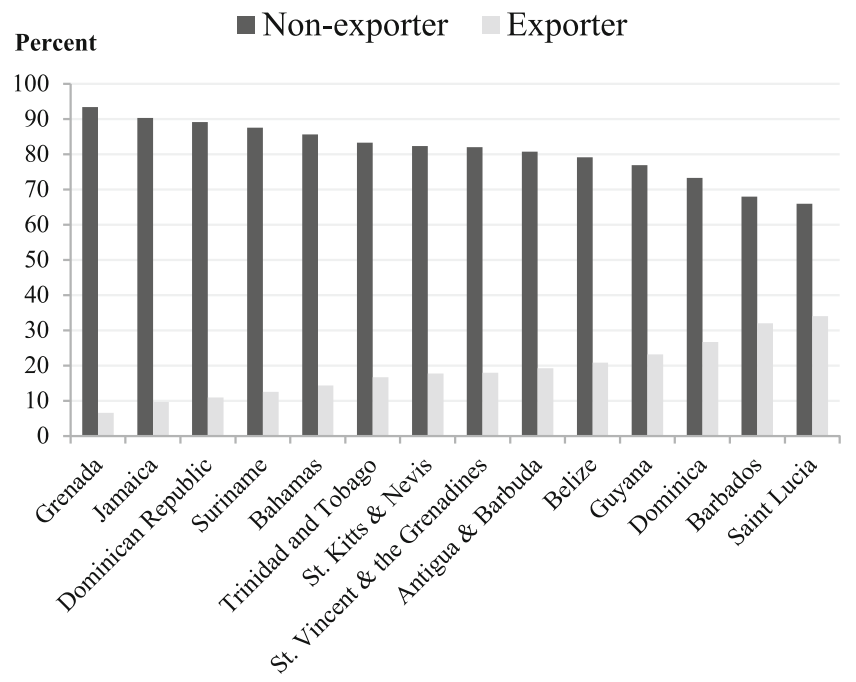

- Domestic Sales $\square$ Indirect Export Sales Direct Export Sales Percent

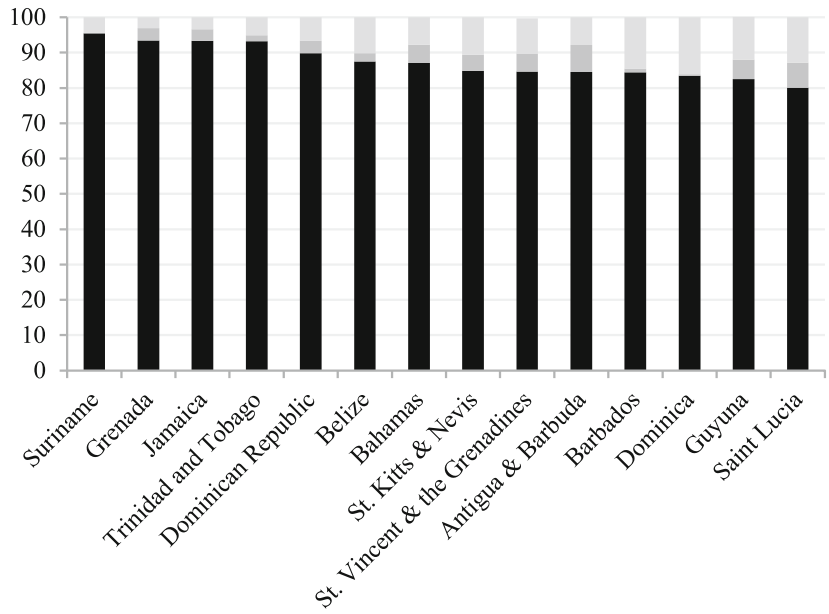

Fig. 7.3 (a) Export status; (b) domestic, indirect, and direct sales Source: Authors' elaboration based on WBES data 
preparatory work along the supply chain is needed on the pre-entry side. For example, in the Caribbean, even fewer firms are engaged in indirect export sales than are in direct export sales.

\section{Principal Characteristics of Human Capital IN THE CARIBBEAN}

Every firm is made up of its people. Just as aggregate productivity is the combination of the productivity of individual firms, each individual firm's productivity is the sum of the productivity of its workers. In this section, we delve into the characteristics of human capital in Caribbean firms, from managers down to workers. Unobservable factors such as the skills of the workforce and managerial capability are often more responsible for the variation in firm performance than are observable firm attributes such as size, age, and international linkages (Jensen and McGuckin 1997). A better understanding of the knowledge, capabilities, and background of the workforce is important, as both the observable and unobservable characteristics of a firm must be included in a complete analysis of firm growth (Laursen et al. 1999).

\section{Entrepreneurs in the Caribbean}

We begin with an analysis of the entrepreneurs (firm owners or managers) in the Caribbean. Recently, some scholars have attributed entrepreneurship with the commercialization of new knowledge and consider it a third driver of economic growth (Vivarelli 2013). ${ }^{10}$ Although the economic literature has long been fascinated with entrepreneurship, not all characterizations describe entrepreneurs as agents of change and economic growth (Wennekers and Thurik 1999). ${ }^{11}$ Although new businesses may contribute to job creation, in order to contribute to productivity, businesses must also grow into their potential (Wagner 2014).

Figure 7.4 shows that firms in the Caribbean are not often created to introduce a new product or idea. Coupled with the fact that firms tend to be mature, this suggests that the majority are not responsible for commercializing new knowledge that would position them as drivers of economic growth. Figure 7.4a shows whether the firm was established out of necessity; the responses vary widely across countries. Figure $7.4 \mathrm{~b}$ shows what type of opportunity motivated the firm's creation. For example, more than $80 \%$ of the firms interviewed in Suriname reported that the business was started because of a lack of better employment opportunities. In contrast, none of the firms in Dominica responded that this was the case. ${ }^{12}$ 
Figure $7.4 \mathrm{~b}$ shows that fewer firms were created to develop a completely new product or idea than to replicate or modify an existing product or idea. The results are similar for both Caribbean countries and Latin American countries (see Chap. 6). These findings are consistent
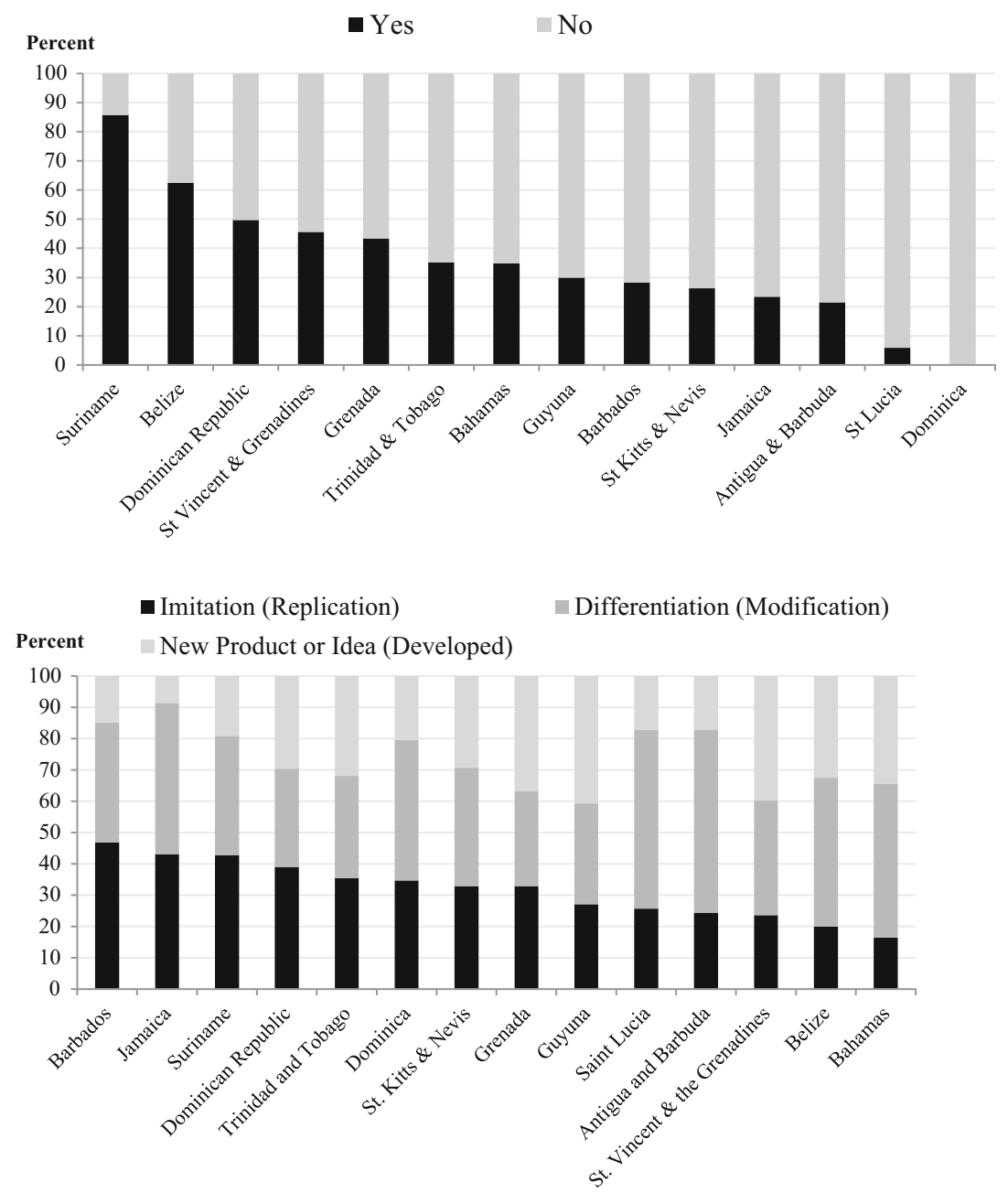

Fig. 7.4 (a) Was the firm established Due to necessity? (b) what type of opportunity motivated the firm's creation?

Source: Authors' elaboration based on WBES data 
with general theories about the dominant nature of innovative business activities in less developed countries (Abramovitz 1989). Data analysis for LAC suggests the same, although studies are largely concentrated on Latin America (Pagés 2010); however, it may not be so different in the Caribbean.

The previous experience of top managers varies widely throughout the Caribbean. In Fig. 7.5 a significant number of countries have some top managers that transitioned from being unemployed into the position. In Suriname, for example, over $10 \%$ of those surveyed transitioned from being unemployed to being employed as a top manager, but this does not seem to be the general trend. On the whole, the top manager tends to have previously held a managerial position that may have provided the impetus to start a new business, especially given that the majority of firms are created to either imitate or replicate existing products or services.

In sum, Caribbean firms tend to replicate, imitate, or differentiate products or services that exist in the market. Further, very few of the firms surveyed are considered high-growth ones. The role of the entrepreneur in transforming an economy rests on the match between available market opportunities and entrepreneurial talent (Naudé 2008). ${ }^{13}$ So,

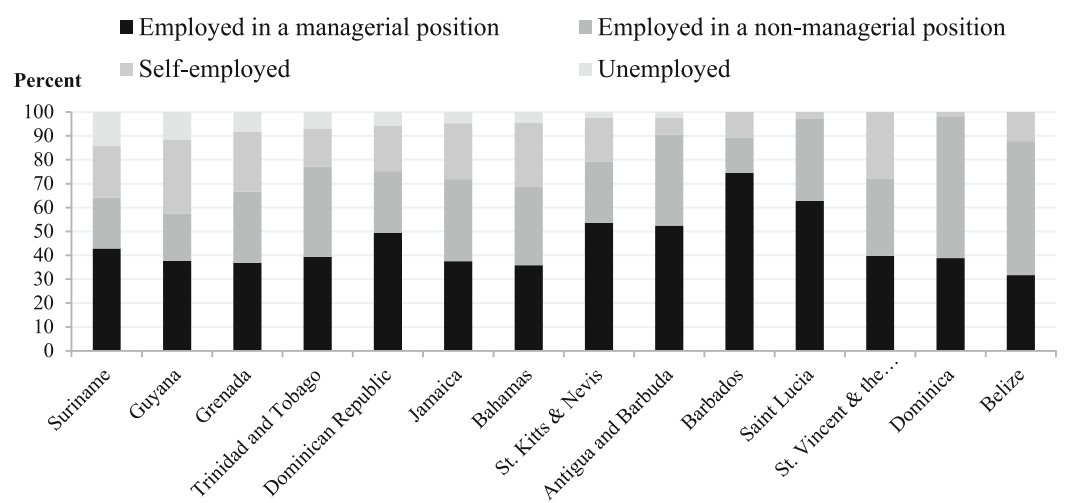

Fig. 7.5 Previous occupation of the Top manager

Source: Authors' elaboration based on WBES data

Notes: Questions about employment in a managerial versus non-managerial position were differentiated in the questionnaire by whether the firm was owned by the respondents' family, but were combined in this figure to reflect only the previous position 
if most of the entrepreneurs in the Caribbean are not commercializing new knowledge, they may be absorbing technology from elsewhere, which requires social capacity to imitate and differentiate—skills also associated with gains in productivity. These skills relate to a broad variety of factors within economies, including but not limited to the general level of education of the workforce, the technical competence of workers, and the amount of technical training provided to workers.

\section{The Caribbean Workforce}

Since 1960, there has been a lot of progress in the Caribbean in terms of attaining primary and secondary education. The region's average years of schooling for the adult population are now on par with the rest of Latin America and approaching Organisation for Economic Co-operation and Development (OECD) averages. The same is not true of transition from secondary to tertiary education. In the firms surveyed, the average percentage of workers with at least a bachelor's degree ranges from 2 in Grenada to 20 in the Dominican Republic. ${ }^{14}$ In addition, pass rates for math and English tests are often below $50 \%$. These signs point to a deeper issue of whether there is a match between skills taught in school and those demanded by employers in the workplace (Caribbean Knowledge Series 2013) (Fig. 7.6).

Finding workers with the right skillset is a major issue in the Caribbean, where over $35 \%$ of firm owners report having unfilled vacancies. An inadequately educated workforce is one of the most often cited obstacles to firm growth in the region (see "Obstacles to Firm Operation in the Caribbean" below). The "right" skills, however, differ by country. On the one hand, in Grenada, Barbados, and Antigua and Barbuda, workers with technical skills are more difficult to find. On the other hand, in Guyana and the Dominican Republic, employers have a slightly harder time finding workers with social skills.

An interesting finding from the PROTEQin data is the variation in the difficulty of finding certain skills by job type (i.e. managerial versus professional). For example, the PROTEQin asks firm owners to rate the difficulty of finding candidates with appropriate skills by different positions within the firm. Figure 7.7 displays the percentage of firm owners who responded that certain skills were very difficult or almost impossible to find in candidates. ${ }^{15}$ The findings are notable. Adequate job-related skills tend to be the most difficult attributes to find in candidates for both managerial 


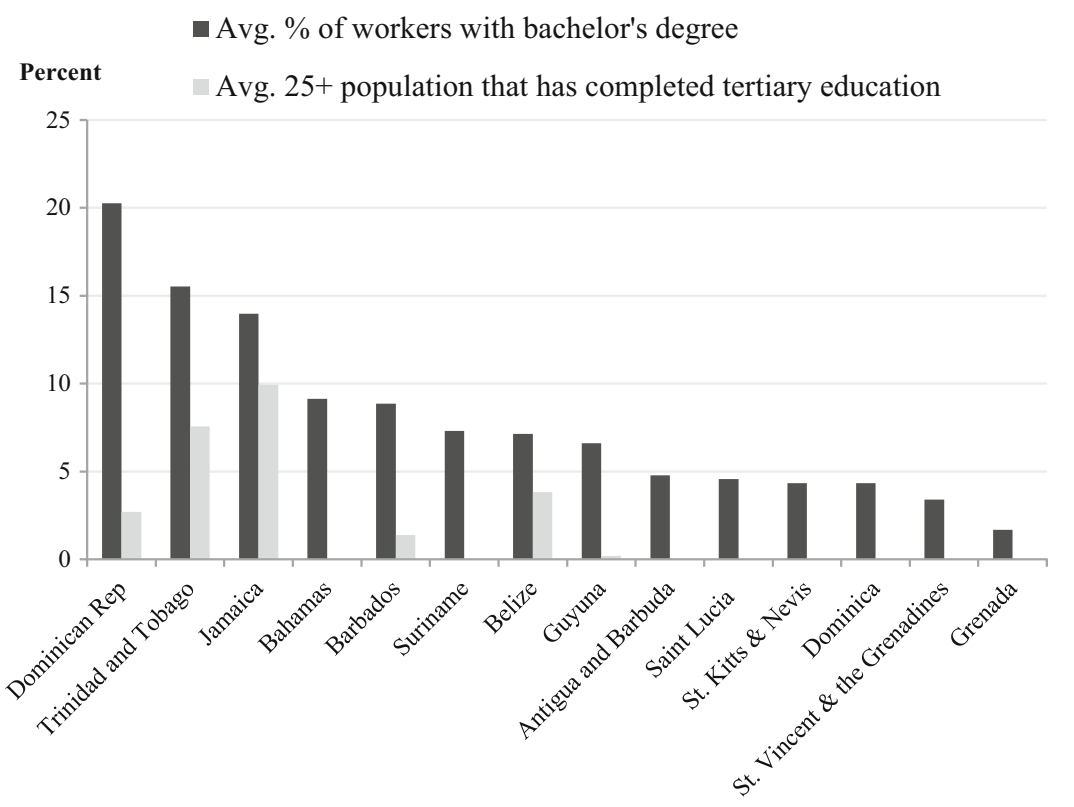

Fig. 7.6 Full-time permanent employees with at least a bachelor's degree and population over age 25 that has completed tertiary education (\%)

Source: Authors' elaboration based on WBES data and Barro and Lee [2010]

and professional positions. On average, almost $30 \%$ of firm owners in this subsample found core skills to be very difficult or almost impossible to find when hiring professionals compared to one-fifth when hiring managers. These results show that, in the Caribbean, there is a lack of adequate skills not only for lower-level workers, but also when seeking capable managers.

When firms were asked in the PROTEQin to identify the importance of various factors causing skill shortages, $52 \%$ cited worker emigration as important, very important, or critical. Considering in the Caribbean net migration is among the highest in the world and that outflows are predominantly migrants with a tertiary education (Nurse and Jones 2009), ${ }^{16}$ it could even be surprising that only $52 \%$ of firms cited worker emigration as such an important factor. It is possible that the diaspora has come to be seen in the Caribbean as a unique source of human capital that provides links to external markets and international customer bases, transfers 


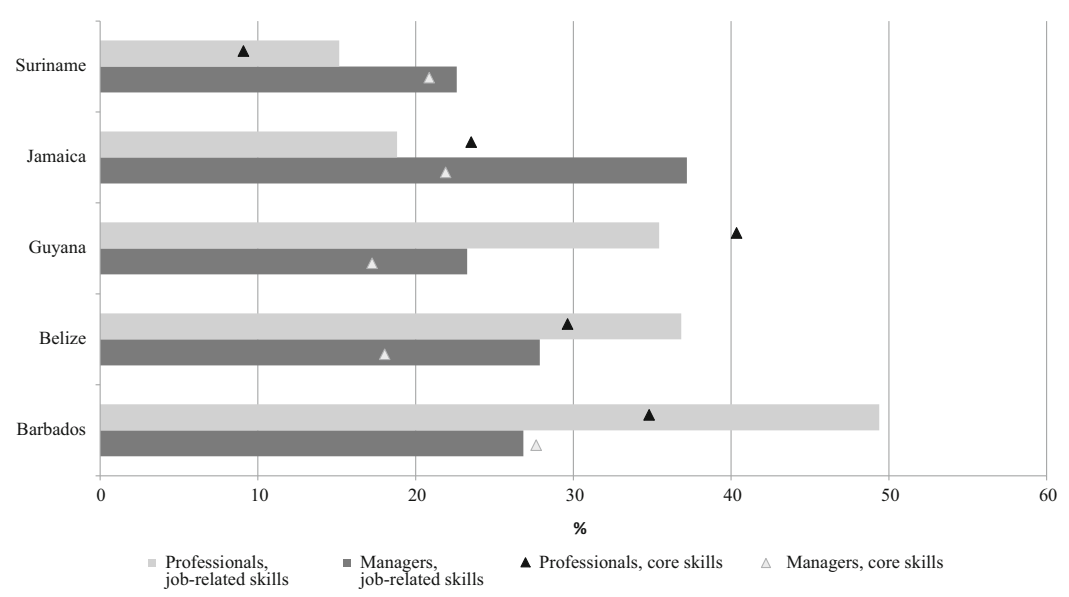

Fig. 7.7 Difficulty finding skills by job type (respondents who cited very difficult or almost impossible)

Source: PROTEQin

Notes: The bars represent the difficulty in finding job-related skills among professionals [light gray] and managers [ dark gray]; the triangles represent the level of difficulty in finding core skills among professionals [dark gray] and managers [ light gray]

industry-specific knowledge, and acts as sources of investment. ${ }^{17}$ Evidence from a recent report suggested around $40 \%$ of the diasporic entrepreneurs surveyed, ${ }^{18} 19$ indicated that they earned some form of revenue from clients in the diaspora. In addition, interviews with large iconic firms in the Caribbean (Suriname, Jamaica, and Guyana) and diasporic firms outside the Caribbean (e.g. New York) revealed these large iconic firms have designed business strategies to target the diasporic customer base (Nurse and Kirton 2014) who then also influence consumer taste in the international markets where they have migrated. While the majority of firms responding to the PROTEQin acknowledged that emigration may deplete local human capital resources, causing skill shortages, they more frequently cited the quality of education or a shortage in the number of local professionals trained by local institutions., ${ }^{20} 21$ They also noted that emigration of workers may provide intangible inputs to local business development, especially through their potential link to an international network and potential customer base outside the country. 
Box 7.2. Education and skills in the Caribbean The PROTEQ in was a first attempt to deepen the micro-data available for the region, and one of the most important areas was education and skill development. The PROTEQin data breaks out education levels of the workforce beyond that included in the WBES. With such a detailed classification, researchers can readily assess the differences in education levels across countries. A cursory analysis finds similar patterns for Barbados, Belize, Jamaica, and Guyana and Suriname. For example, about $80 \%$ of managers in Barbados, Belize, and Jamaica have completed some sort of tertiary education, compared to around $50 \%$ for Guyana and Suriname. Education levels for skilled workers follow a similar pattern as for managers. For less skilled jobs, such as plant and machine operators, firms in Barbados, Belize, and Jamaica tend to employ workers with less education than firms in Guyana and Suriname. Over half of the plant and machine operators in Barbados, Belize, and Jamaica have only completed primary education compared to $29 \%$ in Guyana and $22 \%$ in Suriname.

Despite managers and skilled workers having relatively high levels of educational attainment in Barbados, Belize, and Jamaica, over $60 \%$ of firms in those countries cite a lack of a strong educational background as a major or severe obstacle to productivity. This may be an indication of a mismatch between the skills students are learning in school and the skills desired by the employers in these countries rather than a reflection of low educational attainment. These workforce constraints are less of an issue in Guyana and Suriname, where only around $30 \%$ of firms cited lack of educational background as a major or severe obstacle. This does not mean that it is not an important issue for firm productivity, just that there are likely other, more pressing, obstacles in the firm manager's mind.

\section{Firm Productivity in the Caribbean}

How do the firm characteristics presented above relate to firm performance? Table 7.2 presents the results of an analysis of firm characteristics disaggregated by productivity levels. First, we calculate the average firm labor productivity (sales/employees) for the main product ISIC code in each country. Then, we determine whether the individual firm is above or 
Table 7.2 Firm characteristics by productivity level

\begin{tabular}{|c|c|c|c|c|c|c|c|c|c|}
\hline \multirow[t]{2}{*}{ Firm characteristics } & \multicolumn{3}{|c|}{ Full sample } & \multicolumn{3}{|c|}{ Manufacturing } & \multicolumn{3}{|c|}{ Services } \\
\hline & $N$ & Mean & S.D. & $N$ & Mean & S.D. & $N$ & Mean & S.D. \\
\hline $\begin{array}{l}\text { Irm size (2009) } \\
\text { No. of full-time } \\
\text { ermanent employees) }\end{array}$ & 80 & 51 & 111 & 822 & 665 & 150.7 & 1558 & 42.8 & 82.4 \\
\hline Higher productivity & 1150 & 59.5 & 138 & 474 & 73.4 & 177.3 & 676 & 49.7 & 100.3 \\
\hline Lower productivity & 1230 & 43 & 78.3 & 348 & 57 & 103.4 & 882 & 37.5 & 65 \\
\hline $\begin{array}{l}\text { rm size (2007) } \\
\text { No. of full-time } \\
\text { ermanent employees) }\end{array}$ & 292 & 4 & 128 & 798 & 6 & 18 & 1494 & 40.4 & 80.6 \\
\hline Higher productivity & 1109 & 59.5 & 167 & 462 & 77.8 & 229. & 647 & 46.5 & 99.2 \\
\hline Lower producti & 1183 & 40.4 & 3 & 336 & 51 & & 847 & 8 & 62.4 \\
\hline $\mathrm{rm}$ & 40 & 2 & 20.4 & 8 & 24 & & 25 & 20 & 18.1 \\
\hline Hig & 136 & 23. & 2.5 & 472 & & & 64 & & 18 \\
\hline Lower & 1204 & 19.9 & 18 & 343 & 21.7 & 19.1 & 861 & 19.1 & 17.5 \\
\hline n ownership & , & 15.5 & 2 & 22 & 15.7 & 36.4 & 8 & 15.4 & 1 \\
\hline Higher productivity & 150 & 18 & & 474 & 17 & & 676 & 18 & 39.1 \\
\hline Lowe & 1230 & 13.1 & 33.7 & 348 & 13.8 & 34 & 882 & 12.8 & 33.4 \\
\hline portes & 380 & 17 & 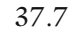 & 822 & 26.6 & & 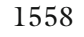 & 1 & 2 \\
\hline High & 150 & 19 & .6 & 474 & 29 & & 76 & 4 & 33 \\
\hline Low & 230 & 14. & 3 & 348 & 22 & 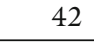 & 882 & .8 & 32.3 \\
\hline $\begin{array}{l}\text { Motive for firm } \\
\text { creation: New product }\end{array}$ & 93 & 29.1 & 45.5 & 285 & 34.4 & 47.6 & 608 & 26.6 & 44.2 \\
\hline Higher & 388 & 29 & & 161 & & & 27 & 1 & 43.5 \\
\hline Lower productivity & 505 & 28.9 & & 124 & & & 381 & 27.6 & 44.7 \\
\hline Iotive for firm & 93 & 3 & 6 & 285 & 34.7 & 7 & 8 & 40 & 49 \\
\hline Higher productivity & 388 & 392 & 9 & 161 & 34 & 6 & 7 & 7 & 49.6 \\
\hline Lower pro & 505 & 37.6 & 48.5 & 124 & 35.5 & 48 & 381 & 38.3 & 48.7 \\
\hline Motive for firm & 893 & 326 & 46.9 & 285 & 30.9 & 46.3 & 608 & 33.4 & 47.2 \\
\hline ity & 8 & & & & & & 27 & 2 & 46.8 \\
\hline Lower productivity & 05 & 33.5 & 47.2 & 124 & 31.5 & 46.6 & 381 & 34.1 & 47.5 \\
\hline Managerial years of & 47 & 18.1 & 4 & 12 & J & .2 & 35 & 17.8 & 1.5 \\
\hline & & & & 46 & & & & & 11.4 \\
\hline Lower & 1213 & 17.8 & 11.4 & 343 & 17.8 & 10.8 & 870 & 17.8 & 11.6 \\
\hline
\end{tabular}


Table 7.2 (continued)

\begin{tabular}{|c|c|c|c|c|c|c|c|c|c|}
\hline \multirow[t]{2}{*}{ Firm characteristics } & \multicolumn{3}{|c|}{ Full sample } & \multicolumn{3}{|c|}{ Manufacturing } & \multicolumn{3}{|c|}{ Services } \\
\hline & $N$ & Mean & S.D. & $N$ & Mean & S.D. & $N$ & Mean & S.D. \\
\hline $\begin{array}{l}\text { Full-time workers } \\
\text { with at least a } \\
\text { bachelor's degree (\%) }\end{array}$ & 2284 & 9.7 & 16 & 794 & 8.5 & 12.6 & 1490 & 10.3 & 17.5 \\
\hline Higher productivity & 1102 & 9.7 & 16.2 & 458 & 8.6 & 13 & 644 & 10.6 & 18.1 \\
\hline Lower productivity & 1182 & 9.6 & 15.8 & 336 & 8.4 & 12.1 & 846 & 10.1 & 17 \\
\hline $\begin{array}{l}\text { Internationally } \\
\text { recognized quality } \\
\text { certification }\end{array}$ & 2299 & 16.8 & 37.4 & 798 & 18.5 & 38.9 & 1501 & 15.9 & 36.6 \\
\hline Higher productivity & 1113 & 17.9 & 38.3 & 459 & 19 & 39.2 & 654 & 17.1 & 37.7 \\
\hline Lower productivity & 1186 & 15.9 & 36.5 & 339 & 18 & 38.5 & 847 & 15 & 35.7 \\
\hline Website & 2370 & 38.2 & 48.6 & 819 & 35.9 & 48 & 1551 & 39.4 & 48.9 \\
\hline Higher productivity & 1146 & 43.2 & 49.6 & 472 & 38.6 & 48.7 & 674 & 46.4 & 49.9 \\
\hline Lower productivity & 1224 & 33.5 & 47.2 & 347 & 32.3 & 46.8 & 877 & 34 & 47.4 \\
\hline $\begin{array}{l}\text { Use of foreign } \\
\text { technology }\end{array}$ & 2380 & 5 & 21.7 & 822 & 14.1 & 34.8 & 1558 & 0.1 & 3.6 \\
\hline Higher productivity & 1150 & 6.4 & 24.5 & 474 & 15.2 & 35.9 & 676 & 0.3 & 5.4 \\
\hline Lower productivity & 1230 & 3.6 & 18.6 & 348 & 12.6 & 33.3 & 882 & 0 & 0 \\
\hline
\end{tabular}

Source: Authors' elaboration based on WBES data

below the average. Then, we analyze the relationship between different firm characteristics and higher performing firms versus lower performing firms. We repeat the exercise for the subsamples of firms in the manufacturing and services sectors.

Table 7.2 shows different patterns for higher and lower productivity levels in relation to various characteristics of firms. Relatively higher productivity firms tended to be larger at the end of 2009 and to have more employees in 2007. The pattern is the same for manufacturing and services, but the average size of manufacturing firms appears to be larger than services. The higher productivity firms are also generally older, have a greater proportion of sales from direct exports, and have more than $10 \%$ foreign ownership. In manufacturing, the higher productivity firms are older, on average, than services firms. In the services sector, higher productivity firms have a greater concentration of foreign ownership. In addition, the proportion of higher productivity firms with direct exports is greater in manufacturing than in services. 
Human capital patterns are as we might expect. Managers of relatively higher productivity firms tend to have slightly more years of experience, on average. Interestingly, the proportion of full-time permanent employees with at least a bachelor's degree is the highest in the relatively higher productivity firms in the services sector.

For technological absorption capacity and usage, different patterns emerge for manufacturing and services based on having a website, using foreign technology, or having an internationally recognized certification. First, a very small proportion of firms in the services sector use technology licensed from a foreign company. Second, a greater proportion of firms in manufacturing have an internationally recognized quality certification (19 versus $16 \%$ in services). Third, a greater proportion of services firms have their own website, which is likely consistent with how critical it is to share information with clients. As mentioned earlier, for firms in services, such as hotels and restaurants, online advertising is becoming increasingly important. Across the board, a greater proportion of higher productivity firms have a website, use foreign technology, or have an internationally recognized certification.

As a robustness check, we conduct a similar analysis using the PROTEQin data. We find many of the same results using the much smaller subset of data. ${ }^{22}$ However, we note a few interesting deviations. First, firms in the five countries are generally slightly older than in the Caribbean as a whole. The average age of low-productivity firms in this subsample is four years older than the average age of low-productivity firms in the 14 Caribbean countries surveyed for the 2010 WBES. The differences are even starker on a sectoral basis, where firms that maintain higher productivity levels are, on average, ten years older than low-productivity firms in the manufacturing sector (the gap is six years in the services sector). In other words, the most productive manufacturing firms tend to be the oldest in this subsample and unproductive services firms tend to be the youngest. In terms of exports, the PROTEQin data shows a much wider gap between the percentage of exporting firms above and below-average productivity levels (33\% of above-average manufacturing firms export versus $18 \%$ of below-average firms). Interestingly, the reverse is true for services, with a larger percentage of low-productivity firms exporting ( $11 \%$ ); only $8 \%$ of services firms with average or aboveaverage productivity levels are exporters. This may signify that services firms are beginning to export before they have the required internal capacities, thus hindering their productivity. 


\section{Obstacles to Firm Operation in the Caribbean}

The WBES asks firm owners a series of questions about their perceived obstacles to current operations. The goal of these questions is to identify particular aspects of the business environment that are constraining firms. Subjective measures of the perceptions of obstacles have been found to be highly correlated with objective measures for the Caribbean specifically (Ruprah and Sierra 2013) and worldwide (Hallward-Driemeier and Aterido 2009). Therefore, in this chapter, we do not question the validity of a particular obstacle being seen as the biggest one, rather we take the firms at their word. Figure 7.8 presents the frequency with which interviewed firms in selected Caribbean countries reported each of the 15 identified obstacles in the survey.

Caribbean firms identify different obstacles as the biggest, which assumes that the most frequently reported obstacle in a country is the one considered to be the most constraining for the majority of firms. For example, in the Bahamas, the highest percentage of firms (34\%) reports lack of an educated workforce as their biggest obstacle; whereas, in Barbados the highest percentage $(28 \%)$ identify access to finance as their biggest obstacle to operations. In Jamaica, $34 \%$ of firms identified tax rates as their biggest obstacle. A recent, in-depth analysis by Nugent and Schmid (2014) confirmed that Jamaica's tax system has long been an issue in the country.

The 2013 PROTEQin data also enabled us to analyze whether the perceptions of primary obstacles have changed for the five PROTEQin countries since the 2010 WBES. Table 7.3 shows that, for the most part, the

Table 7.3 Top obstacle(s) cited by firms, 2010 vs 2013

\begin{tabular}{lll}
\hline & 2010 & 2013 \\
\hline $\begin{array}{l}\text { Barbados } \\
\text { Belize }\end{array}$ & $\begin{array}{l}\text { Access to finance }(28 \%) \\
\text { Inadequately educated } \\
\text { workforce }(17 \%)\end{array}$ & $\begin{array}{l}\text { Electricity }(21 \%) \\
\text { Inadequately educated workforce }(14 \%) ; \\
\text { Crime, theft, and disorder }(14 \%)\end{array}$ \\
Inadequately educated & Electricity $(15 \%)$ \\
Jamaica & workforce (18\%) & Tax rates $(33 \%)$ \\
Suriname & $\begin{array}{l}\text { Inadequately educated } \\
\text { workforce }(30 \%)\end{array}$ & Inadequately educated workforce $(11 \%)$ \\
& & \\
\hline
\end{tabular}

Sources: 2010 data from WBES; 2013 from PROTEQin 
main constraints on firm growth remain unchanged in Belize and Jamaica. While the same holds true in Suriname, the severity of the obstacle (an inadequately trained workforce) decreased by almost two-thirds from 2010, and firms began to cite a wider array of obstacles in 2013. In Barbados, electricity replaced access to finance as the biggest obstacle, and in Guyana, electricity replaced an inadequately trained workforce. Overall, access to finance, a trained workforce, electricity, and tax rates were consistently cited by firms as primary, secondary, or tertiary obstacles to firm growth in 2010 and 2013. Possible explanations for the shifts in the relative importance between particular top obstacles may stem from other changes that the firms in the group surveyed have experienced in the three-year period.

Bahamas

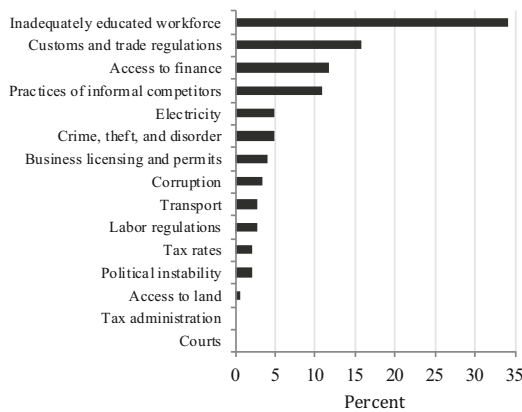

Belize

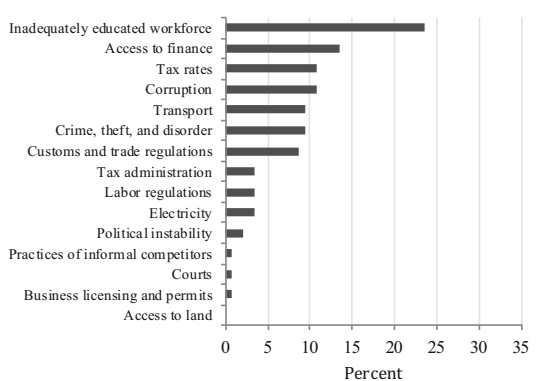

\section{Barbados}

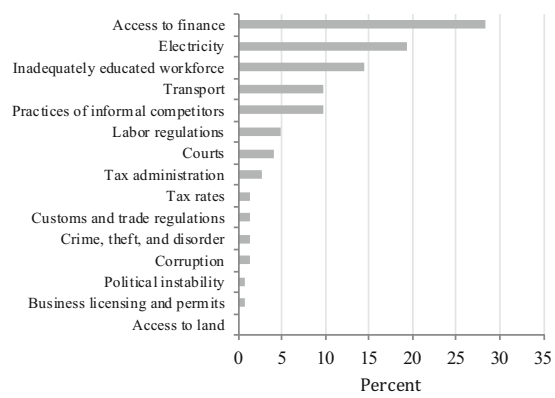

Dominican Republic

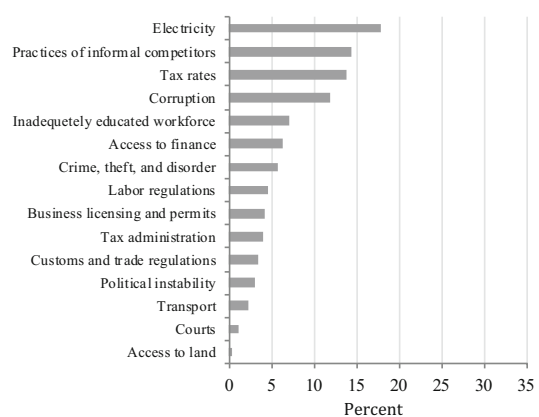

Fig. 7.8 The biggest obstacles by country Source: Authors' elaboration based on WBES data 


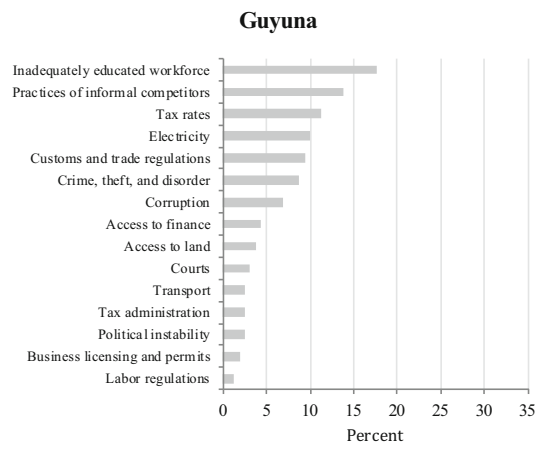

Suriname

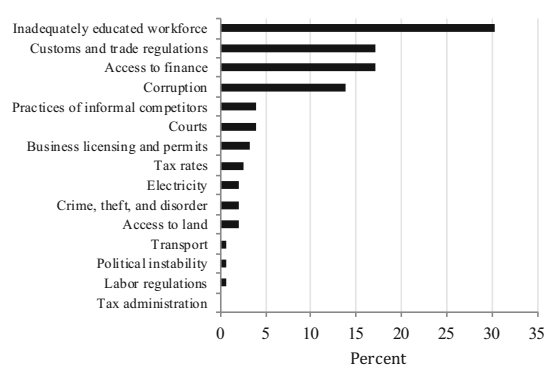

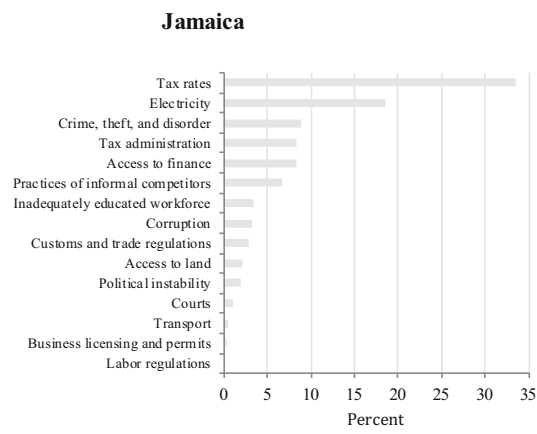

Trinidad and Tobago

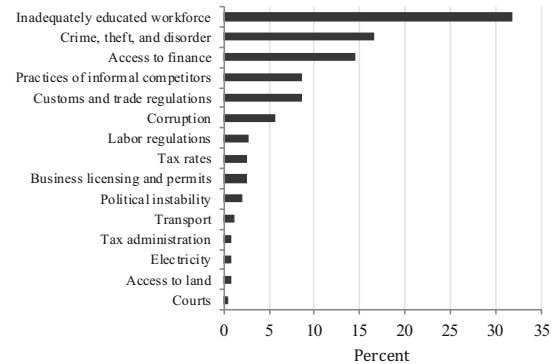

Fig. 7.8 Continued

\section{Are Obstacles Different for Firms in Different Productivity Quintiles?}

The biggest obstacles identified in Figure 7.8 are for all of the firms in a given country. Hallward-Driemeier and Aterido (2009) found that firm characteristics had an impact on the relative importance of obstacles and highlighted the need to look at differences within countries based on firm characteristics. In this vein, we separate firms by labor productivity quintiles to explore whether firms with different levels of labor productivity in the Caribbean identify different primary obstacles to operations.

First we divide the firms evenly into five productivity quintiles where one is the lowest productivity quintile and five is the highest. Table 7.4 visually presents the frequency with which the biggest obstacle is identified by a particular quintile of productivity. In the Bahamas and Barbados, 


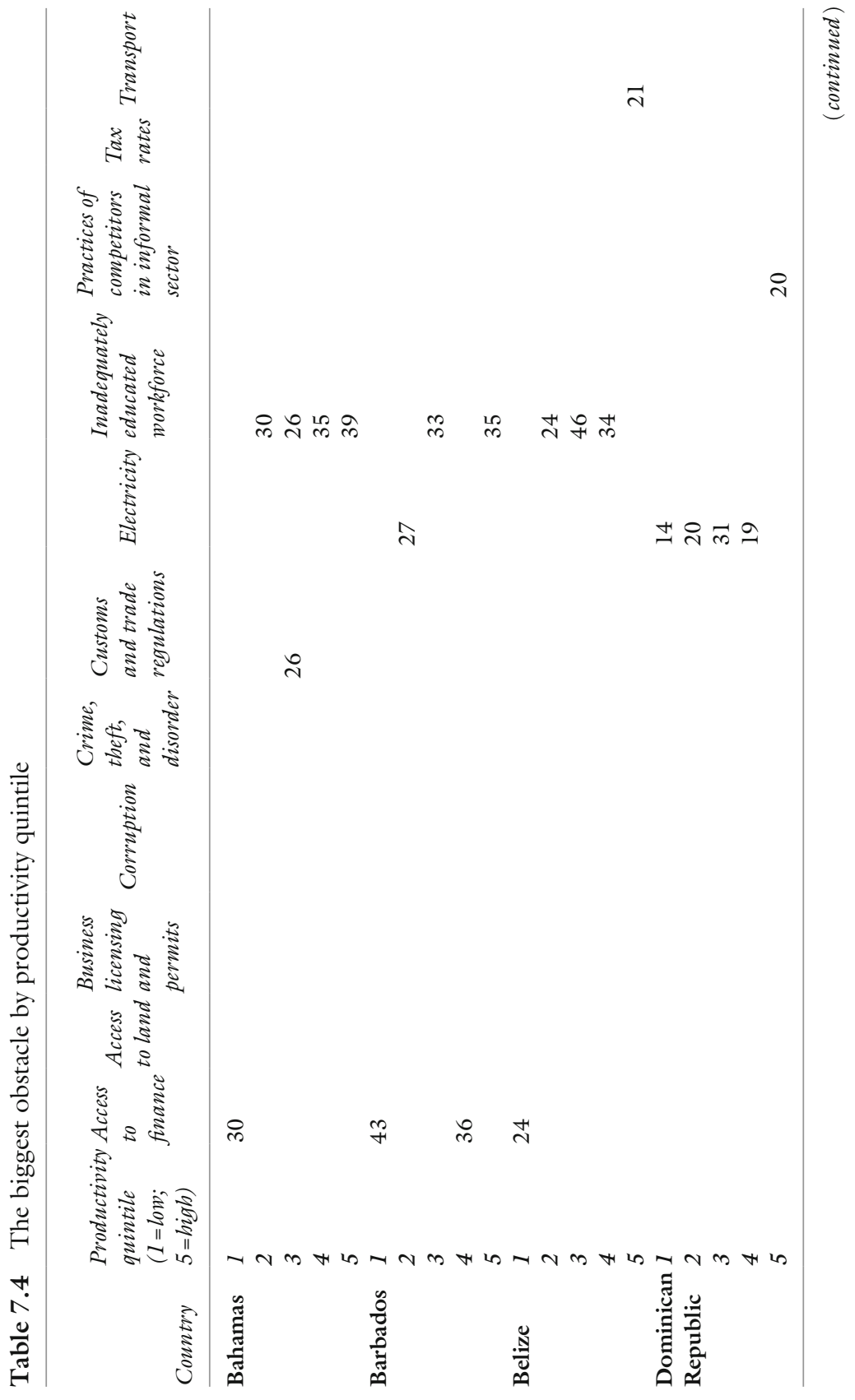




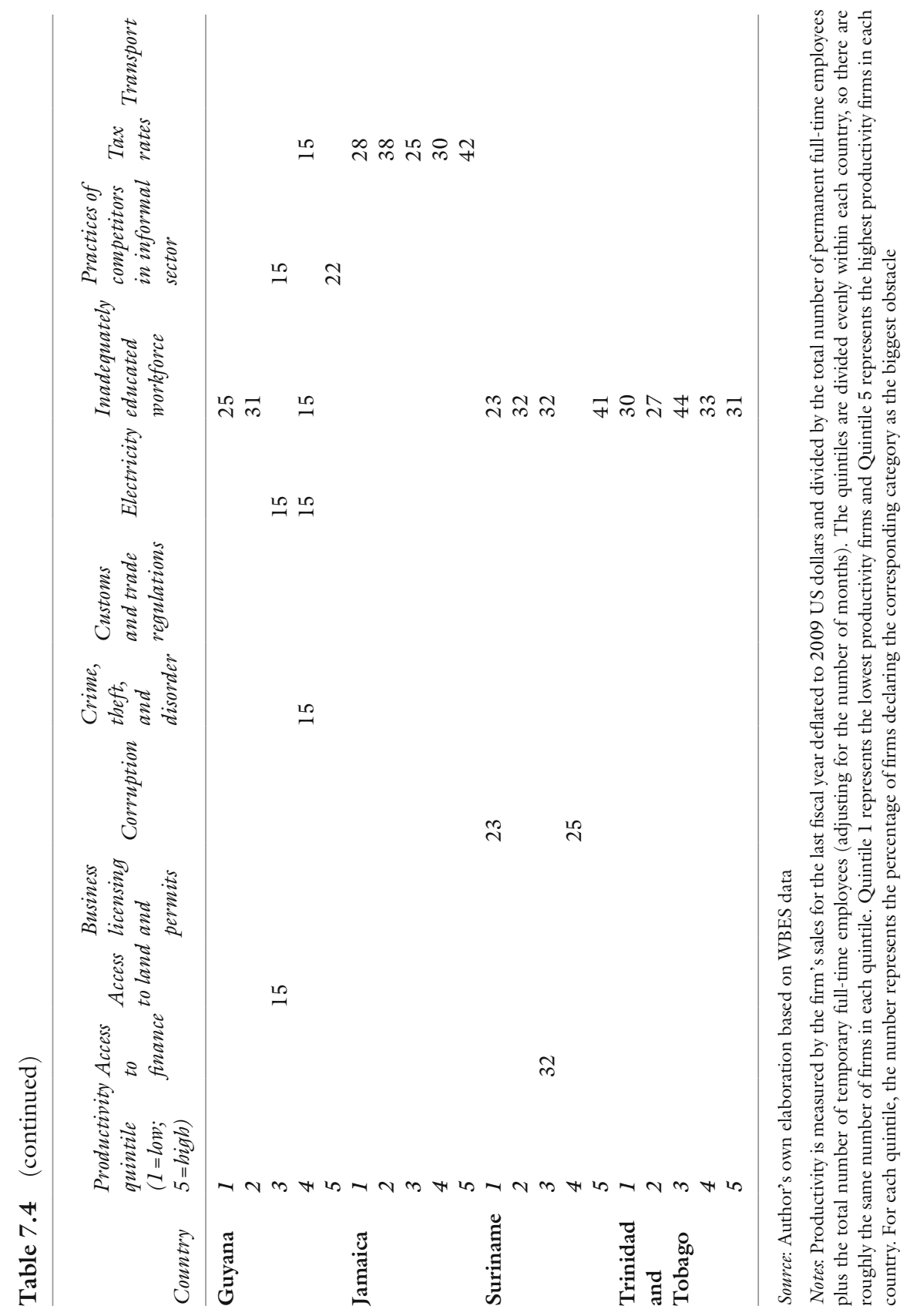


the majority of firms in the lowest productivity quintile identify access to finance as their biggest obstacle. ${ }^{23}$ In the Bahamas, as the productivity quintiles increase, the majority of firms identify an inadequately educated workforce as their biggest obstacle. It is possible that these shifts in identified obstacles reflect increases in exposure to a wider gamut of obstacles as a firm becomes more productive and is faced with more challenges to growth. In the Bahamas, for example, the medium productivity quintile displays an even split between firms that report customs and trade and an inadequately educated workforce as the biggest obstacles. A possible explanation for this could be that these medium productivity firms are at the stage when they are just beginning to export. The relatively lower productivity firms may not be attempting to export yet and thus are not affected by such regulations, while higher productivity firms may already have mastered the red tape and no longer see that as an obstacle. In other countries, such as Jamaica and Trinidad and Tobago, the dominance of a particular obstacle does not differ by productivity quintile. This suggests that the country's business environment may have a feature that affects all businesses and may trump the degree to which the biggest obstacles change according to firms' characteristics.

\section{Econometric Model}

Within economies and within industries, some firms are simply more efficient than others. Using the same measured inputs, high-productivity firms (in the 90th percentile) outperform low-productivity firms by $2: 1$. In India and China, the ratio has been found to be as high as $5: 1$. Further, within-industry dispersion has been found to be on the rise in the United Kingdom (Syverson 2011). Recent publications about innovation and productivity in the LAC region found that firm-level productivity is heterogeneous even within specific economic sectors (log productivity differences between the 90th and 10th percentile were found to be $2.66 \mathrm{log}$ points in services and $2.53 \mathrm{log}$ points in manufacturing). Theory often attributes this to market frictions that can be exacerbated by weaknesses in the institutional environment (Arias Ortiz et al. 2014). The following analysis uses quantile regression techniques following the methodology described in Goedhuys and Sleuwaegen (2009). This methodology is relevant given that the distribution of the dependent variable, labor productivity, is skewed. ${ }^{24,25}$ 
Our interest is in the relationship between perceived obstacles to operation and productivity changes among the different quantiles of the distribution. Since a large number of observations are needed for this type of analysis, we pool the responses of all the firms in all 14 Caribbean countries surveyed for the 2010 WBES. We then list-wise delete the variables with missing values, leaving 2047 observations. The basic model closely follows variables $^{26}$ included in recent work assessing the determinants of productivity in the LAC region using WBES data (Arias Ortiz et al. 2014). We test the model using least squares (LS) and quantile regression techniques.

The basic model is:

\section{$\log$ of Labor Productivity}

$$
\begin{aligned}
= & \alpha+\beta 1 \text { Firm Size }+\beta 2 \text { Age }+\beta 3 \text { Foreign Ownership }+\beta 4 \text { Export } \\
& +\beta 5 \text { Website }+\beta 6 \text { Human Capital }+\beta 7 \text { Biggest Obstacle Finance } \\
& +\beta 8 \text { Biggest Obstacle Edu WF }+\delta \text { Country Dummies } \\
& +\delta 1 \text { Sector Dummies }+\mu
\end{aligned}
$$

where the dependent variable is the log of labor productivity as measured by the firm's total annual sales at the end of the previous fiscal year (in $2009)^{27}$ divided by the number of permanent and temporary ${ }^{28}$ full-time employees at the end of the same previous fiscal year. The firm size is the $\log$ of the firm's response to the number of full-time permanent employees three fiscal years previously (in 2007). Age is a dummy variable that takes the value of 1 if the firm is less than ten years of age. Foreign ownership is a dummy variable that takes the value of 1 if the firm reports that more than $10 \%$ is owned ${ }^{29}$ by foreign individuals, companies, or organizations. Export is a dummy variable that takes the value of 1 if the firm reports more than $10 \%$ of its sales are direct exports. Website is a dummy variable that takes the value of 1 if the firm reports having a website. Human capital is a continuous variable for the percentage of the firm's employees that are reported to have at least a university degree. Biggest obstacle finance is a dummy variable that takes the value of 1 if the firm reports access to finance as its biggest obstacle. Biggest obstacle edu WF is a dummy variable that takes a value of 1 if the firm reports an inadequately educated workforce as its biggest obstacle. We include these two obstacles because they were the most frequently cited in the sample, at 342 for finance and $316^{30}$ for workforce education. We include country dummies to account for country-specific effects, such as the number of ports indi- 


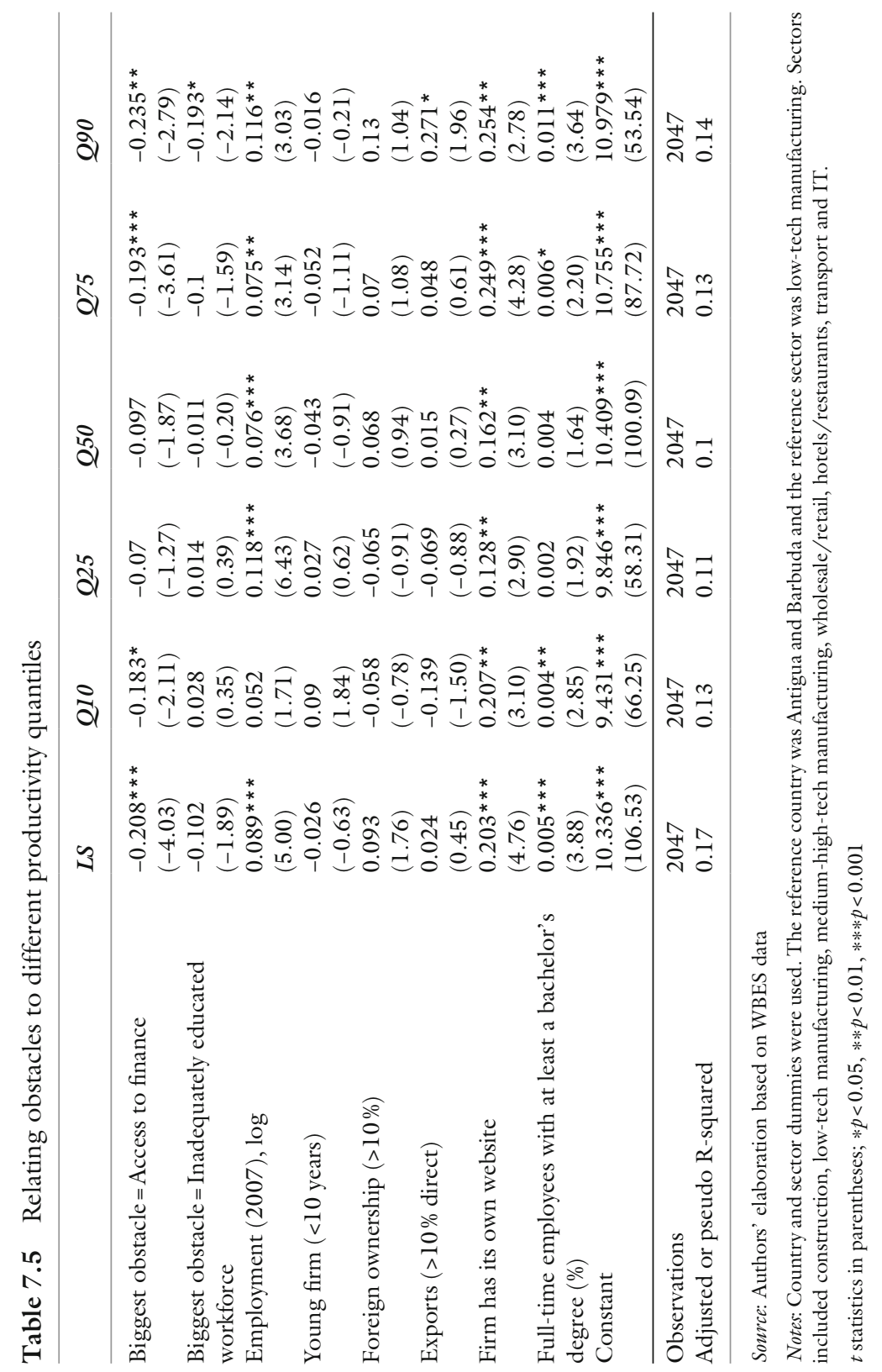


cated in Table 7.1. We include sector dummies to control for differences in productivity among the different sectors, as recent literature suggests is appropriate (Arias Ortiz et al. 2014; Chap. 2 of this book) (Table 7.5).

The results of the LS regression are in line with the results found by Arias Ortiz et al. (2014). In 2007, firm size, whether or not the firm had a website, and human capital were statistically significant. On the other hand, the age of the firm, foreign ownership, and exporter were not statistically significant. This could be due to the fact that firms in the Caribbean tend to be older, on average, than in the rest of LAC. Also, as shown in Chap. 3, there are relatively small proportions of firms in each country that are foreign-owned and similarly relatively small proportions of firms that export. The access to finance obstacle is highly significant and negatively correlated with productivity. The inadequately educated workforce obstacle is not statistically significant, but this changes if the human capital variable is dropped from the equation, at which point it becomes statistically significant. In Table 7.7 (in the Appendix) we present results for just the manufacturing sector, where we include capital per worker. The access to finance obstacle remains significant in the LS regression, but loses significance in the quantile regression analysis. By restricting the sample to manufacturing firms with available data on capital, the number of observations drops to 600 firms, which limits the statistical power. We therefore present it more as a robustness check. We note that some of the other variables respond as expected. Exporter becomes statistically significant and having a website loses significance, which would be consistent with the different nature of business in manufacturing versus services firms.

The estimates for the different quantiles above and in the Appendix are the result of a simultaneous quantile regression that was bootstrapped at the standard 100 repetitions. This means that, while the coefficients and the pseudo R-squared do not change when the regression is run again, the standard errors can change slightly and some of the variables that are on the cusp of significance can change. This can also affect whether the differences between the quantiles are statistically significant. ${ }^{31}$

The results from the analysis should be taken as preliminary evidence that not only do the firm characteristics vary as you move from lower to higher productivity levels, but also that these characteristics may affect performance to varying degrees, depending on where the firms lie in the distribution of labor productivity. One interpretation could be that there are firms in the lowest productivity category in which variables such as lack of access to finance are truly prohibitive. However, there are also slightly 
more productive firms that remain in the lower half of the productivity distribution. Despite reporting access to finance as an obstacle, these firms do not actually perform differently from their counterparts in the same part of the distribution who do not report this as their biggest obstacle. As firms move into higher productivity quantiles, those firms reporting access to finance as their biggest obstacle are indeed under-performing relative to the other firms in their performance quantile who do not report access to finance as their biggest obstacle. The preliminary results corroborate the notion that the characteristics of a firm and the obstacles it faces can indeed vary by and relate differently to productivity.

\section{Conclusion}

The goal of this chapter was to better understand the firms in the Caribbean using micro-data from the WBES and PROTEQin. Since the data deficit has been acknowledged as a challenge for evidenced-based policymaking in the Caribbean, our descriptive data presents firm characteristics from several perspectives. We sought to distinguish whether, after calibrating by main product (or sector) and country, the relatively higher or lower productivity firms show different patterns with respect to the key characteristics linked to productivity. They do. The story of productivity in the Caribbean appears to be consistent with findings outside the region. Therefore, this chapter should serve as a point of departure for further research to gain a deeper understanding of how the characteristics of the private sector in the Caribbean countries exacerbate (or perhaps do not exacerbate) stagnated growth. Preliminary evidence suggests that there is variation in the obstacles identified by relatively higher or lower productivity firms and, perhaps more importantly, individual obstacles such as access to finance associate differently with productivity performance.

This is an original contribution that has rich policy implications for those in the region who wish to tailor or nuance policies to different types of firms in their economies. If policymakers are interested in moving relatively lower productivity firms into the higher productivity realms, they should zero in on the particular obstacles that the relatively lower productivity firms face. If, on the other hand, policymakers are concerned about how to support their relatively higher productivity firms, they should focus on the subset of obstacles reported by those firms. 


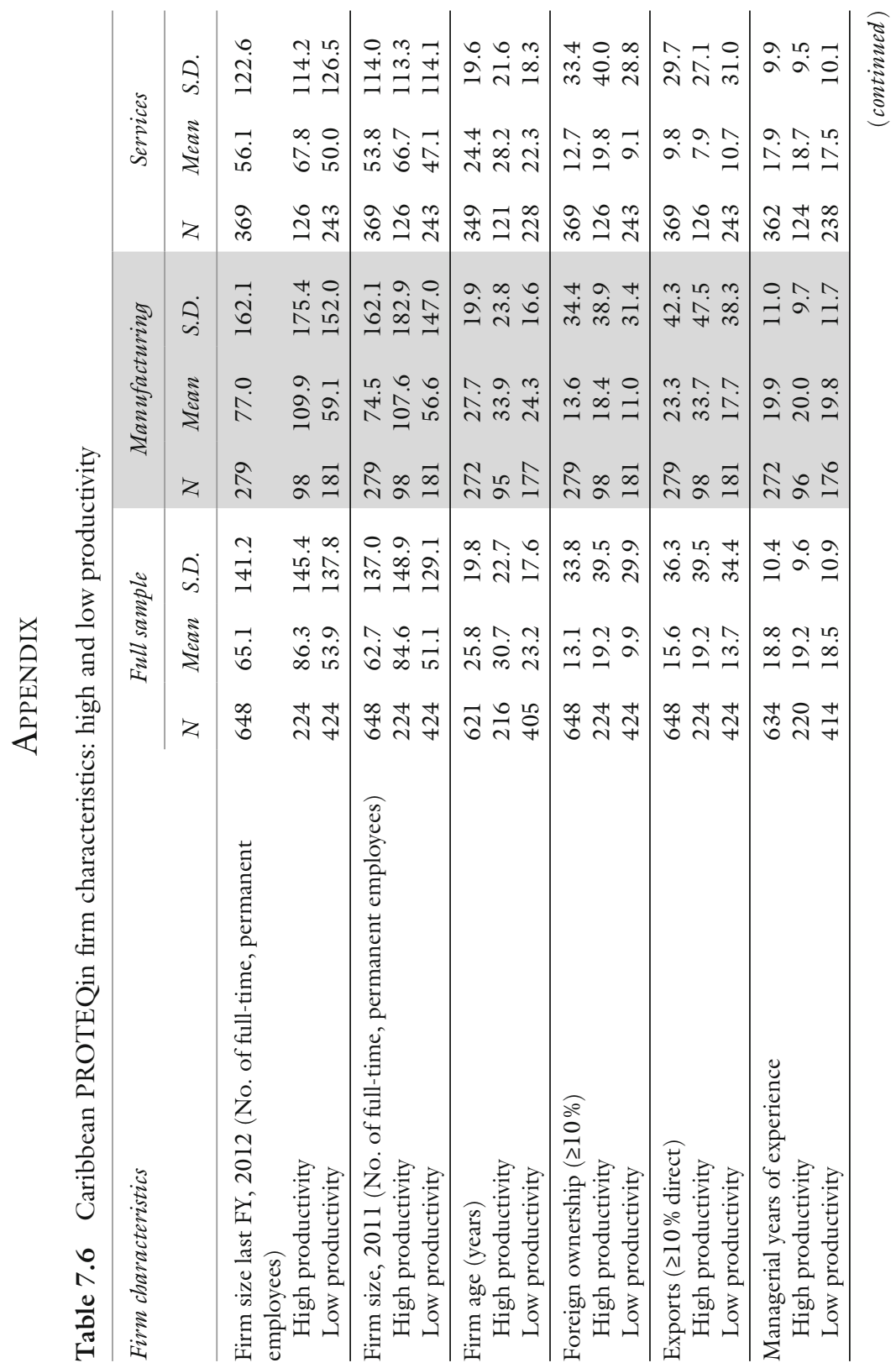




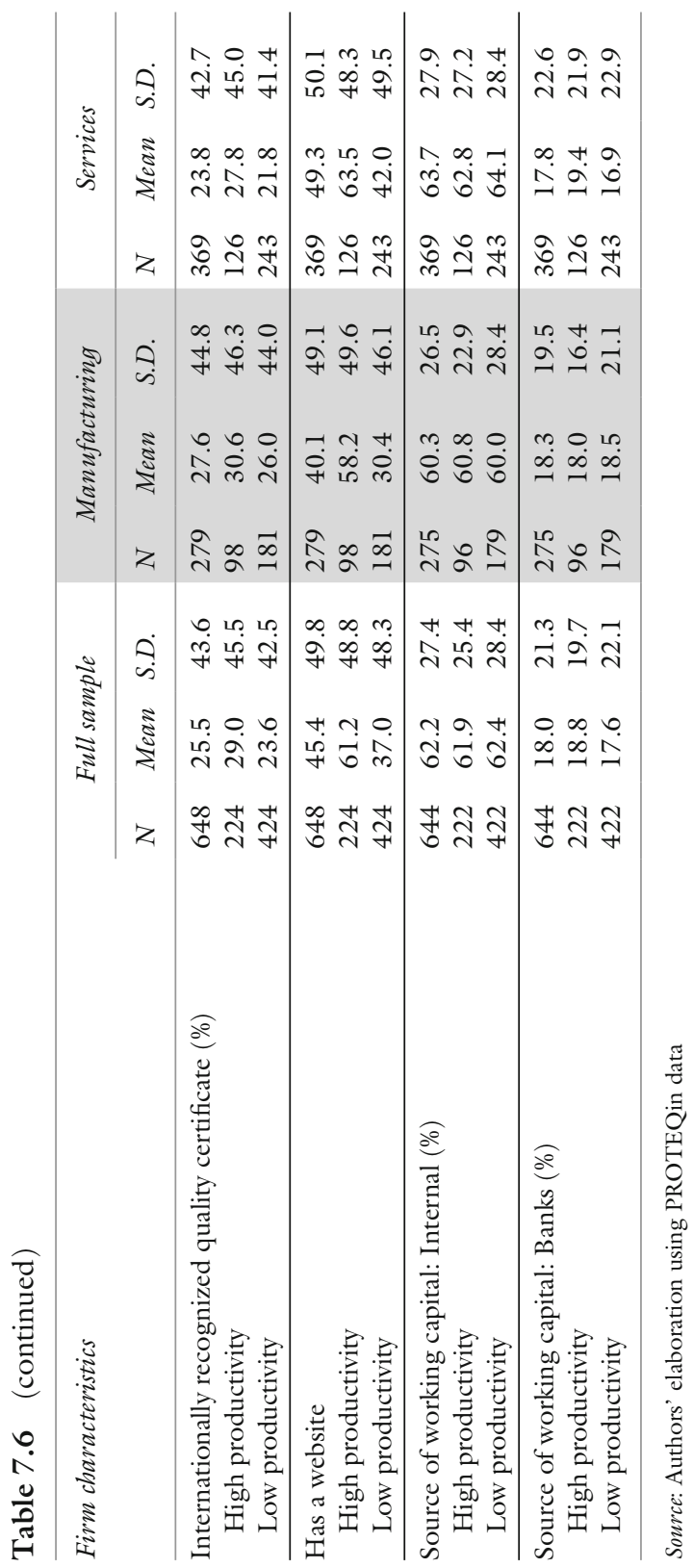




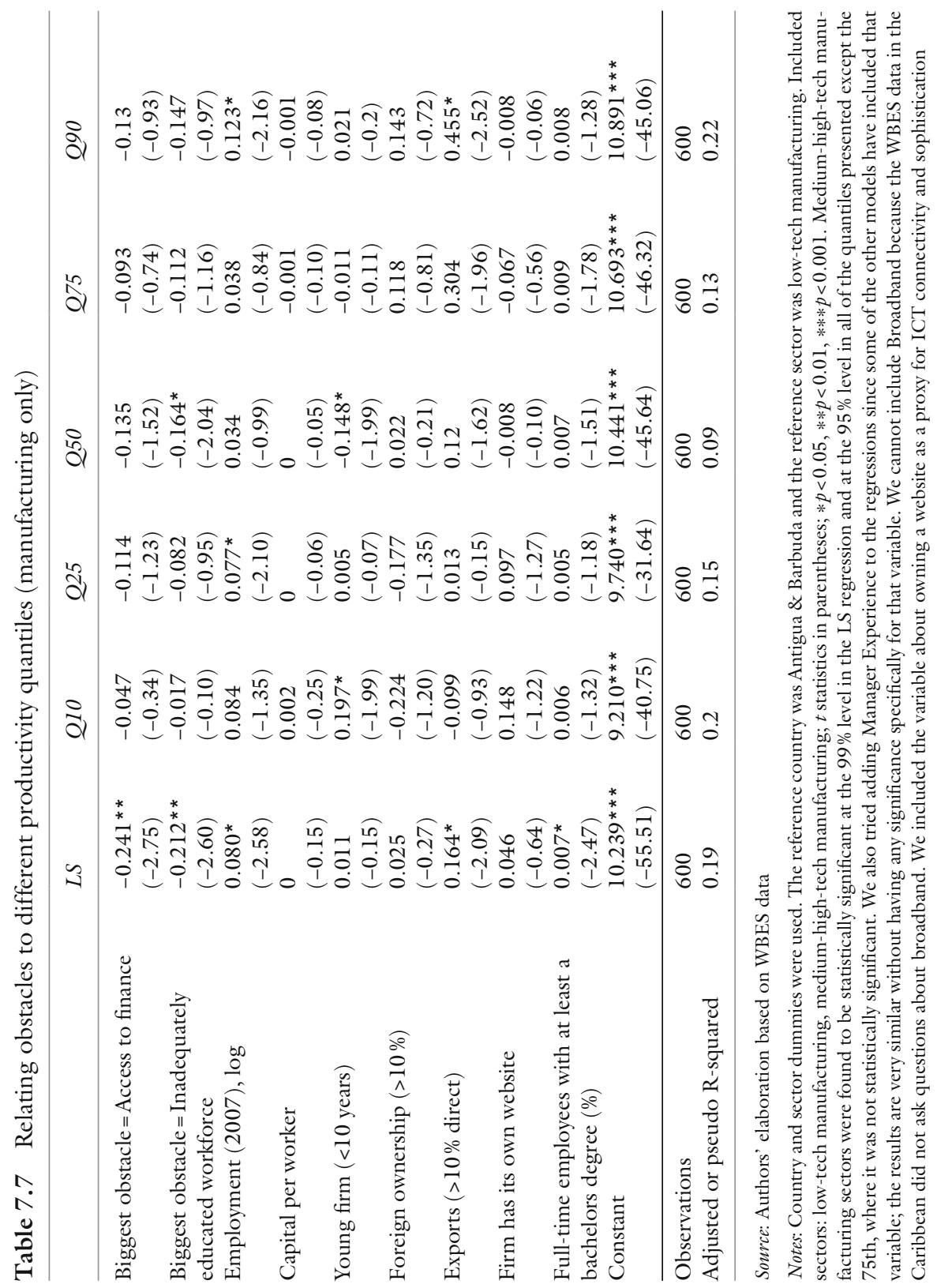




\section{Notes}

1. An exception is Chap. 3, which analyses product and process innovations as drivers of firm performance in the Caribbean.

2. There are specific WBES questionnaires for the Caribbean (manufacturing and services) that contain minor differences from the WBES questionnaires used in Latin America. For example, the Caribbean questionnaires do not ask firms about high-speed broadband connections.

3. Measures of small economies can be based on population, GDP, or land area, which have been found to be highly correlated (Ruprah et al. 2014). To be consistent with other recent publications about the Caribbean, the same definition of small economy has been adopted.

4. In $2006,90 \%$.

5. For more information, see www.competecaribbean.org

6. In some instances, firms that were not included in the 2010 round of WBES were added in the 2013 survey.

7. Francis et al. (2014) used slightly different country groupings for the Caribbean. In their note, they used small countries: Antigua and Barbuda, The Bahamas, Barbados, Belize, Dominica, Grenada, Guyana, Suriname, St. Kitts \& Nevis, Saint Lucia, and St. Vincent \& the Grenadines.

8. The regional average for LAC cellphone usage was $88 \%$ (2010 WBES). In 2010, Jamaica and Guyana were both below this threshold but well surpassed it in the 2013 PROTEQin.

9. The article describes self-selection as more productive or more ambitious, and forward-looking firms as those preparing themselves to opt into markets with foreign competition. This is in contrast to the post-entry learning-by-exporting perspective: once you are an exporter, you must increase your productivity to survive the competition, but you also benefit from the positive externalities offered by involvement with international suppliers and competitors.

10. Building on growth theorists who attribute growth to human capital and $\mathrm{R} \& \mathrm{D}$, these recent scholars postulate that entrepreneurship links investment in new knowledge (R\&D) and economic growth (Vivarelli 2013).

11. See Szirmai et al. (2011) for a recent study of entrepreneurship as it relates to innovation and economic development.

12. An important consideration regarding whether a firm was created due to lack of a better opportunity is that the WBES excludes firms that are smaller than five employees. A concentration of firms that are started for lack of better employment may exist in firms that were excluded from the survey.

13. Here the author's literal phrase "structural transformation" is interpreted as transformation.

14. The proportion of the population that has completed tertiary educationa broader measure than a bachelor's degree-is $10 \%$ or less. However, in 
the Barro and Lee dataset (1950-2010), this variable is only available for five of the surveyed countries, supporting what is mentioned at the outset of this chapter, namely that when it comes to commonly used indicators, many of the Caribbean countries suffer from a deficit of data.

15. The questions are based on a five-point scale from "not difficult" to "almost impossible."

16. Biene et al. (2008) offered empirical evidence that brain drain is detrimental.

17. For example, Gibson and McKenzie (2011) raised questions about the existence of brain gain and proposed ideas to frame the empirical analysis of a series of understudied aspects of the impact of highly skilled migration.

18. Diasporic entrepreneurs are defined as entrepreneurs who are tapping into the Caribbean or diaspora markets.

19. A total of 67 diasporic firms responded to an online survey. The sample was mainly gathered from Compete Caribbean's registered database of entrepreneurs that responded to the open call for the Caribbean Idea Marketplace (CIM).

20. Of the firms surveyed by PROTEQin $79 \%$ cited the quality of education as a factor ranging from important to critical in causing skill shortages and almost $77 \%$ cited a shortage in the number of local professionals trained by local institutions.

21. A shortage in local professionals trained by local institutions could also be affected by people who migrate away from the Caribbean to pursue educational opportunities elsewhere (Thomas-Hope 2002).

22. See Table 7.6 in the Appendix for complete results.

23. Hallward-Driemeier and Aterido (2009) pointed out that endogeneity remains a concern with the obstacle of access to finance. In other words, it may be precisely because these firms have low productivity that they experience access to finance as their biggest obstacle. That does not mean that they are not objectively experiencing this obstacle.

24. Goedhuys and Sleuwaegen (2009) confronted a skewed distribution of their dependent variable and, as they describe, classical regression approaches are a location shift where the covariates are conditioned to the mean and are interpreted as being associated with a shift in the mean, but not in the shape or distribution of the dependent variable. They used quantile regression because they were interested in the factors that stretched the tail of distribution and had a strong effect where the high-growth firms were located.

25. Since the mean could be distorted by outliers in the tail of the distribution.

26. This model differs from some of the other approaches used in other chapters of this book because of the necessity to focus on the services sector, 
which is extremely relevant in the Caribbean. Therefore, we choose to closely follow Arias Ortiz et al. (2014)), who used an approach readily applicable to our analysis. For example, we initially do not include capital per worker in our model because capital is not available in the survey for the services sector. In order to check how the results would differ, we perform the same analysis for the manufacturing sector only. The results are presented in Table 7.7 in the Appendix.

27. Standardized in the dataset by deflating all responses to 2009 US dollars.

28. Correcting for the number of months of the year during which the temporary employees were working.

29. In the sample there were 12 observations of the 2047 that were categorized in the dataset as state-owned enterprises; these 12 observations were included as domestically owned (and took a value of zero).

30. The next most frequently cited biggest obstacle (by 238 firms) was electricity.

31. In this case, the following variables are statistically different at the $95 \%$ level among the quantiles: employment in 2007 (size of the firm), full-time employees with at least a bachelor's degree, and exports. The biggest obstacle being access to finance was significantly different at the $90 \%$ level.

\section{REFERENCES}

Abramovitz, M. 1989. Thinking About Growth and Other Essays on Economic Growth and Welfare in Studies in Economic History and Policy: The United States in the Twentieth Century. L. Galambos and R. Gallman (eds.). Cambridge: Cambridge University Press.

Arias Ortiz, E.A., G. Crespi, E. Tacsir, F. Vargas, and P. Zuniga. 2012. Innovation for Economic Performance: The Case of Latin American and Caribbean Firms. Technical Note IDB-TN-494. Washington, DC: IDB.

Arias Ortiz, E., G. Crespi, A. Rasteletti, and F. Vargas. 2014. Innovation and Productivity in Services in Latin America and the Caribbean. Discussion Paper: IDB-DP-346. Washington, DC: IDB.

Ayyagari, M., A. Demirguc-Kent, and V. Maksimovic. 2011. Small vs. Young Firms Across The World: Contribution to Employment, Job Creation and Growth. Policy Research Working Paper 5631. Washington, DC: The World Bank.

Barro, R., and J.W. Lee. 2010. A New Data Set of Educational Attainment in the World, 1950-2010. Journal of Development Economics 104: 184-198.

Biene, M., F. Docquier, and H. Rapoport. 2008. Brain Drain and Human Capital Formation in Developing Countries: Winners and Losers. The Economic Journal 118(April): 631-652.

Caribbean Knowledge Series. 2013. Quality Education Counts for Skills and Growth. LAC 78597. Washington, DC: The World Bank. 
Crespi, G., E. Tacsir, and F. Vargas. 2014. Innovation and Productivity in Services: Evidence from Latin America. Technical Note IDB-TN-690. Washington, DC: IDB.

Francis, D., J.L. Rodriguez Meza, and J. Yang. 2014. Mapping Enterprises in Latin American and the Caribbean. Latin America and the Caribbean Series, Note 1, Rev. 8/2014. Washington, DC, and Christ Church, Barbados: The World Bank Group, IDB, and Compete Caribbean.

Gibson, J., and D. McKenzie. 2011. Eight Questions about Brain Drain. Policy Research Working Paper 5668. Washington, DC: The World Bank.

Goedhuys, M., and L. Sleuwaegen. 2009. High-Growth Entrepreneurial Firms in Africa: A Quantile Regression Approach. Research Paper 2009(11). Helsinki, Finland: United Nations University World Institute for Development Economics Research (UNU-Wider).

Hallward-Driemeier, M., and R. Aterido. 2009. Comparing Apples with ... Apples. How to Make (More) Sense of Subjective Rankings of Constraints to Business. Policy Research Working Paper 5054. Washington, DC: The World Bank.

IDB. 2011 a. Innovation in Services: The Hard Case for Latin America and the Caribbean. Discussion Paper IDB-DP-203. Washington, DC: IDB.

IDB. 2011b. The Region's Place in the Digital World: A Tale of Three Divides. In Development Connections: Unveiling the Impact of New Information Technologies, ed. A. Chong. Washington, DC: IDB and Palgrave Macmillan.

Jensen, J.B., and R.H. McGuckin. 1997. Firm Performance and Evolution: Empirical Regularities in the U.S. Microdata. Industrial and Corporate Change 6(1): 25-47.

Kaluza, P., A. Kolzsch, M. Gastner, and B. Blasiu. 2010. The Complex Network of Global Cargo Ship Movements. Journal of the Royal Society Interface 7(48): 1093-1103.

Laursen, K., V. Mahnke, and P. Vejrup-Hansen. 1999. Firm Growth from a Knowledge Structure Perspective. Frederiksberg, Denmark: Department of Industrial Economics and Strategy, Copenhagen Business School.

Naudé, W. 2008. Entrepreneurship in Economic Development. Research paper/ UNUWIDER2008/20.

Nugent, S., and J.P. Schmid. 2014. The Business Climate in Jamaica: What Does the Enterprise Survey Have to Say? Policy Brief No. IDB-PB-211. Washington, DC: IDB.

Nurse, K., and J. Jones. 2009. Brain Drain and Caribbean-EU Labour Mobility. Cave Hill, Barbados: Shridath Ramphal Centre for International Trade Law, Policy and Services, UWI.

Nurse, K., and C. Kirton. 2014. Caribbean Diasporic Entrepreneurship: Analytical Report. Washington, DC: IDB.

Pagés, C. (ed.). 2010. The Age of Productivity: Transforming Economies from the Bottom Up. Washington, DC: IDB and Palgrave Macmillan. 
Ruprah, I., and R. Sierra. 2013. Laments of the Caribbean Businessperson Are Based on Facts? Policy Brief No. IDB-PB-205. Washington, DC: IDB.

Ruprah, I., K. Melgarejo, and R. Sierra. 2014. Is There a Caribbean Sclerosis? Stagnating Economic Growth in the Caribbean. Monograph 178. Washington, DC: IDB.

Syverson, C. 2011. What Determines Productivity? Journal of Economic Literature 49(2): 326-365.

Szirmai, A., W.A. Naudé, and M. Goedhuys. 2011. Entrepreneurship, Innovation, and Economic Development. Oxford: Oxford University Press.

Thomas-Hope, E. 2002. Skilled Labour Migration from Developing Countries: Study on the Caribbean Region. International Migration Papers 50. Geneva: International Migration Programme, International Labour Organization.

Vivarelli, M. 2013. Is Entrepreneurship Necessarily Good? Microeconomic Evidence from Developed and Developing Countries. Industrial and Corporate Change 22(6): 1453-1495.

Wagner, J. 2005. Exports and Productivity: A Survey of the Evidence from Firm Level Data. Working Paper Series in Economics 4:1860-5508. Lüneburg, Germany: Lüneburg University.

Wagner, R. 2014. Promoting Entrepreneurship: The Start-Up and Scale-Up of High-Productivity Firms. In Development in the Americas: Rethinking Productive Development: Sound Policies and Institutions for Economic Transformation, ed. G. Crespi, E. Fernández-Arias, and E. Stein. Washington, DC: IDB and Palgrave Macmillan.

Wennekers, S., and R. Thurik. 1999. Linking Entrepreneurship and Economic Growth. Small Business Economics 13(1): 27-56.

(c) (1) (-) $\fallingdotseq$ Except where otherwise noted, this work is licensed under a Creative (c) At ${ }_{\text {gr }}$ No Commons Attribution-NonCommercial-NoDerivatives 3.0 IGO License. To view a copy of this license, visit https://creativecommons.org/licenses/ by-nc-nd/3.0/igo/ 